\title{
Pengaruh Pembiayaan Mudharabah dan Pembiayaan Musyarakah Terhadap Laba Bersih PT. Bank BRI Syariah
}

\author{
Fitria Yulia Sari, Nahruddien Akbar \\ Universitas Singaperbangsa Karawang \\ Correspondence email: 1710631030079@student.unsika.ac.id, kjasduc@gmail.com
}

\begin{abstract}
Abstrak Penelitian ini memiliki tujuan yaitu untuk mengetahui dan dilakukan pengujian pembiayaan mudharabah dan musyarakah ada atau tidaknya pengaruh terhadap laba bersih pada PT Bank BRI Syariah tahun 2018-2020. Penelitian ini menggunakan metode deskriptif kuantitatif dengan menggunakan data sekunder yang berasal dari laporan keuangan berupa data pembiayaan mudharabah, pembiayaan musyarakah dan laba bersih setelah pajak dari tahun 2018 sampai dengan tahun 2020. Pada penelitian ini menggunakan alat analisis yaitu regresi linear berganda. Aplikasi SPSS 23.0 digunakan untuk menguji data dalam penelitian ini. Pembiayaan mudharabah dan musyarakah berdasarkan hasil analisis data menunjukkan bahwa terhadap laba bersih secara bersama-sama berpengaruh signifikan. Pengujian analisis data ini menunjukkan bahwa pembiayaan mudharabah terhadap laba bersih tidak berpengaruh signifikan, artinya jika terjadi kenaikan ataupun penurunan pada pembiayaan mudharabah tidak akan berpengaruh pada laba bersih Bank. Sebaliknya, pada pembiayaan musyarakah terhadap laba bersih berpengaruh signifikan dan positif, artinya semakin besar pendapatan yang diperoleh melalui pembiayaan musyarakah maka akan meningkatkan laba bersih Bank.
\end{abstract}

Kata Kunci: Pembiayaan Mudharabah, Pembiayaan Musyarakah, Laba Bersih

\begin{abstract}
This research has the objective of knowing and testing mudharabah and musyarakah financing whether or not there is an effect on net income at PT Bank BRI Syariah in 2018-2020. This research uses a quantitative descriptive method using secondary data derived from financial reports in the form of mudharabah financing data, musyarakah financing and net profit after tax from 2018 to 2020. This research uses an analytical tool, namely multiple linear regression. The SPSS 23.0 application was used to test the data in this study. Mudharabah and musyarakah financing based on the results of data analysis show that the net income together has a significant effect. This data analysis test shows that mudharabah financing on net income does not have a significant effect, meaning that if there is an increase or decrease in mudharabah financing, it will not affect the bank's net profit. Otherwise, musyarakah financing has a significant and positive effect on net income, meaning that the greater the income earned through musyarakah financing, the higher the Bank's net profit.
\end{abstract}

Keywords: Mudharabah Financing, Musyarakah Financing, Net Profit

\section{PENDAHULUAN}

Pertumbuhan ekonomi di Indonesia yang menghadapi banyak perkembangan mengakibatkan permintaan publik akan kebutuhan pendanaan bartambah, baik pendanaan untuk kebutuhan konsumtif ataupun produktif. Dalam hal ini perbankan selaku lembaga keuangan suatu negara, khususnya di bidang ekonomi serta keuangan memegang peranan penting. Peran bank sebagai lembaga menjadi sarana bagi masyarakat yang mempunyai dana lebih serta masyarakat yang memerlukan dana.

Indonesia merupakan sebuah negara di Asia Tenggara dengan banyak penduduk yang beragama islam, bahkan terbanyak di dunia. Selaku sebuah negara berpenduduk mayoritas muslim, hal ini akan memicu dalam meningkatkan kinerja industri berbasis syariah, salah satunya pada sektor perbankan.

Perkembangan industri perbankan syariah di Indonesia sendiri semakin mengalami perkembangan dan memberikan kontribusi yang positif untuk mendukung inklusi keuangan dikhususkannya bagi masyarakat yang ingin menggunakan jasa keuangan yang memenuhi prinsip syariah.

Dalam penerapannya, perbankan syariah mempunyai dasar hukum yang sesuai dengan syariat/hukum Islam. Pada perbankan syariah tidak mengenal adalnya sistem suku bunga pinjaman, dikarenakan dalam islam bunga pinjaman dinilai haram serta mengandung unsur riba. Bank Syariah menyalurkan dana dan dipakai oleh para nasabah. Kemudian keuntungan yang diperoleh dari bagi hasil (nisbah) dengan nasabah. Sistem bagi hasil (nisbah) yang diterapkan bank syariah, kala penandatanganan akad (perjanjian) baik pihak bank ataupun pihak nasabah sama-sama mengetahui prosesnya.

Bank BRI Syariah merupakan suatu bank yang memakai hukum yang berlandaskan islam dalam melaksanakan aktivitas usahanya. Tujuan didirikannya Bank BRI Syariah sama seperti perusahaan lainnya yaitu untuk menghasilkan keuntungan. Yang terpenting, jika bank terus menerus mendapatkan laba maka kedepannya akan terjaminnya kelangsungan hidup badan usaha tersebut.

Produk-produk yang ditawarkan di oleh perbankan syariah selain memberikan kemudahan bagi para nasabahnya, juga memberikan keuntungan untuk pihak bank itu sendiri. Keuntungan itu dapat diketahui dari jumlah laba yang dihasilkan bank tersebut yang terletak pada laporan keuangan.

Menurut Harahap (2008, hal. 144), laba memiliki 
arti pertumbuhan dalam dagang dalam bahasa arab. Ribh berarti jual beli, sedangkan rabihah berarti perdagangan yang artinya laba atau hasil dagang. Menurut Islahuzzaman (2012, hal. 238) laba dihitung antara total pendapatan dikurangi oleh biaya-biaya yang digunakan oleh aktivitas bisnis perusahaan dalam kurun waktu tertentu. Menurut Kasmir (2014, hal. 303) laba bersih mengacu pada laba setelah dikurangi dengan beban perusahaan yang dimana pajak termasuk didalamnya, dalam kurun periode tertentu. Jika pembiayaan telah disalurkan kepada para nasabah, maka bank akan memperoleh laba bersih. Bersarnya jumlah pendapatan yang diterima bank atas pembiayaan yang telah diterima nasabah dari bank sangat berpengaruh pada besarnya keuntungan yang bank syariah akan hasilkan. Jika jumlah pembiayaan yang disalurkan semakin banyak kepada para nasabah maka perolehan pendapatan bank juga akan semakin besar. Maka dari itu, semakin meningkatnya pendapatan akan berdampak pada tingkat laba bersih bank.

Mudharabah menurut Ismail (2011, hal. 168) merupakan perjanjian kerjasama usaha diantara dua pihak ataupun lebih. Dari pihak bank atau shahibul maal di dalam akad mudharabah melakukan penyertaan modalnya sebesar $100 \%$, sedangkan dari nasabah (mudharib) memiliki peran yaitu mengelola usaha. Kemudian akan dilakukan perjanjian/kesepakatan perhitungan porsi jumlah bagi hasil. Jika terdapat perolehan keuntungan dari kerjasama usaha akan dihitung dan dilakukan bagi hasil sesuai dengan perjanjian tersebut. Pengelola usaha harus memiliki rasa tanggung jawab dalam mengelola usaha tersebut. Jika terdapat keutungan, akan dilakukan pembagian sesuai dengan kontrak yang tertulis. Sebaliknya, pemilik modal akan menanggung kerugian jika suatu saat terjadi hal tersebut. Kecuali jika pengelola usaha lalai dan menyebabkan terjadinya kerugian tersebut, maka pengelola usaha atas kerugian tersebut harus bertanggung jawab penuh (Alma \& Donni, 2014, hal. 14).

Musyarkah menurut Ascarya (2011, hal. 51) merupakan partner usaha dua orang atau lebih dalam menjalankan bisnis dengan melakukan kesepakatan kerjasama. Dalam penyertaan modal tiap-tiap pihak harus ikut berpartisipasi serta turut dalam melakukan pengelolaan bisnis tersebut. Apabila memperoleh keuntungan dan terjadi kerugian akan dilakukan pembagian sesuai dengan persentase modal yang disertakannya. Musyarakah artinya mencampur yang mana diambil dari bahasa Arab. Menurut Sudarsono (2004, hal. 67) berarti menggabungkan atau mencampurkan modal satu dengan modal yang lain, oleh karena itu tidak dapat di pisahkan antara satu dengan lainnya. Bank syariah tidak menyediakan semua modal dalam pembiayaan musyarakah, tetapi modal yang diberikan merupakan sebagian dari total keseluruhan modal yang diperlukan. Bank syariah dapat memberikan modal berdasarkan jumlah yang disepakati dengan nasabah, misalnya dari total modal yang dibutuhkan bank syariah memberikan sebesar $70 \%$, sedangkan dari total modal yang dibutuhkan nasabah memberikan sebesar $30 \%$.

Tabel 1

Pembiayaan Mudharabah, Pembiaya an Musyarakah dan Laba Bersih pada PT Bank BRI Syariah (dalam jutaan rupiah)

\begin{tabular}{|c|r|r|r|}
\hline Tahun & $\begin{array}{c}\text { Pembiayaan } \\
\text { Mudharabah }\end{array}$ & $\begin{array}{c}\text { Pembiayaan } \\
\text { Musyarakah }\end{array}$ & $\begin{array}{c}\text { Laba } \\
\text { Bersih }\end{array}$ \\
\hline $\mathbf{2 0 1 8}$ & 484.847 & 7.748 .129 & 106.600 \\
\hline $\mathbf{2 0 1 9}$ & 414.096 & 11.383 .021 & 74.016 \\
\hline $\mathbf{2 0 2 0}$ & 315.016 & 14.665 .380 & 248.054 \\
\hline
\end{tabular}

Sumber: www.idx.co.id. data diolah

Berdasarkan pada tabel 1, pembiayaan mudharabah pada tahun 2019 mengalami penurunan kemudian pada tahun 2020 mengalami kenaikan. Sebaliknya pembiayaan musyarakah cenderung mengalami peningkatan tiap tahunnya. Sedangkan pada laba bersih perusahaan terlihat mengalami penurunan pada tahun 2019 kemudian pada tahun 2020 mengalami kenaikan.

Berdasarkan fenomena tersebut, sebelumnya telah dilakukan penelitian. Menurut penelitian terdahulu yang dilakukan oleh Monika (2019) mengungkapkan bahwa kedua variabel yaitu pembiayaan mudharabah dan musyarakah secara simultan terhadap laba bersih memiliki pengaruh pada Bank Mandiri Syariah.

Penelitian sebelumnya yang dilakukan oleh Nurawwalunnisa (2017) mengungkapkan bahwa variabel pembiayaan mudharabah secara parsial terhadap laba bersih memiliki pengaruh pada perbankan syariah Indonesia.

Penelitian sebelumnya yang telah dilakukan oleh Suaidah (2020) mengungkapkan bahwa variabel pembiayaan musyarakah secara parsial terhadap laba bersih memiliki pengaruh pada PT. Bank Syariah Bukopin.

Berdasarkan penelitian terdahulu, yang membedakannya dengan penelitian yang dilakukan saat ini yaitu pada objek penelitian yang diteliti. Pada penelitian ini lokus yang dipakai menggunakan PT Bank BRI Syariah. Selain itu rentang waktu yang diteliti pada penelitian ini yaitu pada tahun 2018 sampai dengan tahun 2020.

\section{METODE}

Pada penelitian ini menggunakan metode analisis data yaitu metode deskriptif kuantitatif dengan mengolah data keuangan perusahaan. Objek pada penelitian ini merupakan perusahaan perbankan yang terdaftar di Bursa Efek Indonesia (BEI) yaitu PT Bank 
BRI Syariah. Teknik analisis yang digunakan yaitu regresi linier berganda. Sedangkan alat yang digunakan untuk melakukan pengujian pada data menggunakan software SPSS 23.0. SPSS adalah program untuk mengolah data statistik. Penelitian ini dalam penyusunannya menggunakan rumus uji data yaitu Uji Asumsi Klasik, Uji Regresi Linier Berganda dan Uji Koefisien Determinasi.

Data dikumpulkan dengan metode dokumentasi yaitu berupa data sekunder. Data tersebut berasal dari laporan keuangan bulanan yang telah dipublikasikan oleh portal resmi BEI (Bursa Efek Indonesia) serta pada portal resmi PT Bank BRI Syariah.

\section{HASIL DAN PEMBAHASAN}

Uji Asumsi Klasik

Uji asumsi klasik pada penelitian ini terdiri dari uji normalitas, uji multikolonieritas, uji heterokedastisitas dan uji autokorelasi (Ghozali, 2017).

Berdistribusi normal atau tidaknya pada model regresi tersebut dapat diketahui pada hasil uji grafik $P$ - $P$ Plot. Berdasarkan gambar 1 bahwa model regresi yang dihasilkan telah berdistribusi normal, dimana grafik dibawah terlihat adanya penyebaran data mengikuti arah garis diagonal.

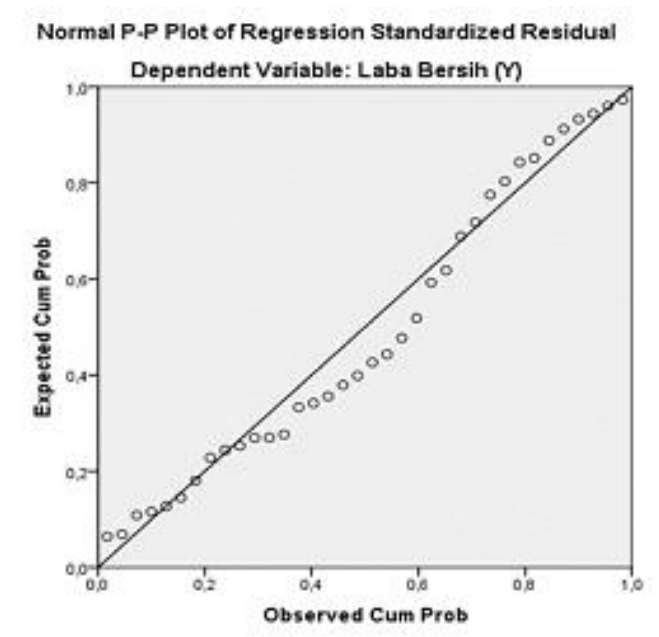

Gambar 1

Grafik Hasil Uji Norma litas

Sumber: Data diolah dengan SPSS 23.0

Berdasarkan pada perhitungan SPSS bahwa kedua variabel independen tidak terjadi multikolinearitas. Nilai VIF $<10$ serta pada nilai toleransi $>0,10$. Hal ini terlihat dari besarnya toleransi variabel pembiayaan mudharabah dan pembiayaan musyarakah sebesar 0,321 $>0,10$. Sedangkan nilai VIF 3,115 $<10$.

Pada gambar 2 terlihat bahwa titik-titik tidak berbentuk suatu pola tertentu serta menyebar secara acak dan baik pada atas ataupun bawah angka 0 pada sumbu Y. Maka dapat dismpulkan bahwa model regresi yang digunakan tidak terdapat masalah heteroskedastisitas.

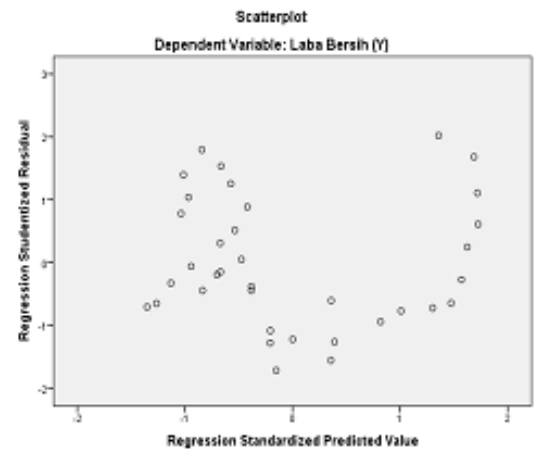

Gambar 2

Grafik Hasil Uji Heteroskedastisitas

Sumber: Data diolah dengan SPSS 23.0

Terdapat atau tidaknya korelasi pada suatu persamaan dapat diketahui dengan melakukan uji autokorelasi. Tidak terjadi autokorelasi, jika DW berada di antara -2 atau +2 atau $-2 \leq \mathrm{DW} \leq+2$. Pada hasil uji autokorelasi yang dilakukan dengan SPSS 23.0 didapatkan nilai DW sebesar 0,294. Dikarenakan nilai ini terletak antara -2 dan +2 . Artinya model regresi yang dipakai layak digunakan karena tidak terdapat autokorelasi.

\section{Regresi Linear Berganda}

Untuk menguji signifikansi pengaruh antar variabel dapat menggunakan alat analisis uji $\mathrm{F}$ serta uji $\mathrm{t}$ dengan tingkat signifikansi 5\% $(0,05)$.

a. Uji F (F -test)

Tabel 2

Hasil Uji F (Secara Simultan)

ANOV ${ }^{a}$

\begin{tabular}{|ll|r|c|c|}
\hline \multicolumn{2}{|l|}{ Model } & \multicolumn{1}{c|}{ df } & F & Sig. \\
\hline $1 \quad$ Regression & 2 & 9,725 &, $000^{\mathrm{b}}$ \\
& Residual & 33 & & \\
& Total & 35 & & \\
\hline
\end{tabular}

Sumber: Data diolah dengan SPSS 23.0

Pada tabel 4 jika dilihat dapat diketahui bahwa $F_{\text {hitung }}(9,725)>F_{\text {tabel }}(3,276)$ dan besar tingkat signifikan $0,000<0,05$. Dimana $\mathrm{H}_{0}$ ditolak sedangkan $\mathrm{H}_{\mathrm{a}}$ diterima. Jadi kesimpulannya pembiayaan mudharabah dan musyarakah secara simultan terhadap laba bersih berpengaruh positif signifikan.

\section{b. Uji t (t- test)}

Hasil analisis ditunjukkan pada tabel berikut ini. 
Fitria Yulia Sari dan Nahruddien Akbar, Pengaruh Pembiayaan Mudharabah dan Pembiayaan Musyarakah Terhadap Laba Bersih PT. Bank BRI Syariah

\begin{tabular}{|c|c|c|c|c|}
\hline & $\begin{array}{r}\text { Tab } \\
\text { Hasil R }\end{array}$ & $\begin{array}{l}3 \\
\text { gresi }\end{array}$ & & \\
\hline \multirow{2}{*}{ Variabel } & \multicolumn{2}{|c|}{$\begin{array}{c}\text { Unstandardized } \\
\text { Coefficients }\end{array}$} & \multirow[b]{2}{*}{$\mathrm{t}$} & \multirow[b]{2}{*}{ Sig. } \\
\hline & B & Std. Error & & \\
\hline Constant & $-201993,726$ & 99924,441 & $-2,021$ &, 051 \\
\hline Mudharabah &, 224 &, 117 & 1,925 &, 063 \\
\hline Musyarakah & 019 &, 005 & 3,835 &, 001 \\
\hline
\end{tabular}

Berdasarkan hasil dari tabel 3, maka dapat dikembangkan model persamaan regresi menunjukkan bahwa:

$Y=-201993,726+0,224 X_{1}+0,019 X_{2}$ atau

Laba Bersih $=-\mathbf{2 0 1 9 9 3 , 7 2 6}+$ 0,224 (Pembiayaan

Mudharabah) + 0,019 (Pembiayaan Musyarakah).

Dari rumus tersebut dapat disimpulkan bahwa nilai tanda negatif sebesar -201993,726 menunjukkan bahwa jika nilai pembiayaan mudharabah dan pembiayaan musyarakah adalah nol, maka laba bersih mengalami penurunan. sebesar 201993,726. Besar koefisien regresi yaitu 0,224 pada pembiayaan mudharabah $\left(\mathrm{X}_{1}\right)$ dimana jika variabel tersebut mengalami peningkatan sebesar $1 \%$ serta variabel bebas lainnya konstan, maka laba bersih meningkat sebesar 0,224 . Dengan melihat nilai koefisien regresi pada pembiayaan mudharabah sebesar 0,224 berarti antara perhitungan pembiayaan mudharabah dan laba bersih terdapat pengaruh positif. Besar koefisien regresi yaitu 0,019 pada pembiayaan musyarakah $\left(\mathrm{X}_{2}\right)$ sebesar 0,019 dimana jika variabel tersebut mengalami peningkatan sebesar $1 \%$ serta variabel bebas lainnya konstan, maka laba bersih meningkat sebesar 0,019. Dengan melihat nilai koefisien regresi pada pembiayaan musyarakah sebesar 0,019 berarti antara perhitungan pembiayaan musyarakah dengan laba bersih terdapat pengaruh yang positif.

Jika dilihat pada output koefisien yang terdapat pada tabel 3 dapat diketahui bahwa pengaruh pembiayaan mudharabah terhadap laba bersih, pada variabel pembiayaan mudharabah nilai $t_{\text {hitung }}(1,925)<$ nilai $t_{\text {tabel }}(2,030)$ dengan tingkat signifikan sebesar 0,063 $>0,05$ yang artinya $\mathrm{H}_{0}$ diterima sedangkan Ha ditolak. Jadi dapat ditarik kesimpulan bahwa pembiayaan mudharabah secara parsial terhadap laba bersih tidak berpengaruh dan tidak signifikan. Jika dilihat berdasarkan tabel pengaruh pembiayaan musyarakah terhadap laba bersih, pada variabel pembiayaan musyarakah nilai $\mathrm{t}_{\text {hitung }}(3,835)>$ nilai $\mathrm{t}_{\text {tabel }}(2,030)$ dengan tingkat signifikan sebesar 0,001 $<0,05$ yang artinya $\mathrm{H}_{0}$ ditolak sedangkan $\mathrm{H}_{\mathrm{a}}$ diterima. Jadi dapat ditarik kesimpulan bahwa pembiayaan musyarakah secara parsial terhadap laba bersih berpengaruh signifikan.

\section{Koefisien Determinasi (R2)}

Jika dilihat dari hasil uji koefisien determinasi berdasarkan perhitungan SPSS 23.0 bahwa nilai $\mathrm{R}$ Square menunjukkan angka 0,371 maka variabel pembiayaan mudharabah $\left(\mathrm{X}_{1}\right)$ serta pembiayaan musyarakah $\left(\mathrm{X}_{2}\right)$ tidak terlalu berpengaruh kuat terhadap laba bersih (Y) dan hanya memiliki pengaruh sebesar $37,1 \%$. Sedangkan sisanya sebesar $62,9 \%$ dipengaruhi oleh faktor lain yang tidak diteliti dalam penelitian ini.

\section{Pengaruh Pembiayaan Mudharabah $\left(\mathbf{X}_{1}\right)$ dan Pembiayaan Musyarakah $\left(\mathbf{X}_{2}\right)$ Terhadap Laba Bersih}

Berdasarkan hasil penelitian ini pada pembiayaan mudharabah $\left(\mathrm{X}_{1}\right)$ dan pembiayaan musyarakah $\left(\mathrm{X}_{2}\right)$ terhadap laba bersih (Y) dengan tingkat signifikan sebesar 0,000 dimana lebih kecil dari 0,05 maka, terdapat pengaruh signifikan pembiayaan mudharabah dan pembiayaan musyarakah terhadap laba bersih. Pada penelitian ini mengungkapkan bahwa secara simultan pembiayaan mudharabah dan pembiayaan musyarakah mempengaruhi laba bersih secara positif.

Hasil penelitian ini tidak sejalan dengan penelitian yang telah dilakukan oleh Monika (2019) tentang pengaruh pembiayaan mudharabah dan pembiayaan musyarakah trhadap laba bersih Bank Syariah Mandiri.

\section{Pengaruh Pembiayaan Mudharabah $\left(\mathrm{X}_{1}\right)$ Terhadap Laba Bersih}

Berdasarkan hasil penelitian ini pada pembiayaan mudharabah $\left(\mathrm{X}_{1}\right)$ terhadap laba bersih (Y) dengan tingkat signifikan sebesar 0,063 dimana lebih besar dari 0,05 maka, tidak terdapat pengaruh pembiayaan mudharabah terhadap laba bersih. Artinya, jika terjadi kenaikan ataupun penurunan pada pembiayaan mudharabah tidak akan berpengaruh pada laba bersih pada PT Bank BRI Syariah.

Hasil penelitian ini tidak sejalan dengan penelitian yang telah dilakukan oleh Nurawwalunnisa (2017) tentang pengaruh pembiayaan mudharabah terhadap laba perbankan syariah Indonesia.

\section{Pengaruh Pembiayaan Musyarakah $\left(\mathbf{X}_{2}\right)$ Terhadap Laba Bersih}

Berdasarkan hasil penelitian ini pada pembiayaan musyarakah $\left(\mathrm{X}_{2}\right)$ terhadap laba bersih $(\mathrm{Y})$ dengan tingkat signifikansi 0,001 lebih kecil dari 0,5 maka, terdapat pengaruh signifikan pembiayaan musyarakah terhadap laba bersih. Pada penelitian ini mengungkapkan bahwa secara parsial pembiayaan musyarakah mempengaruhi laba bersih secara positif. Artinya, jika semakin besar pendapatan yang diperoleh melalui pembiayaan musyarakah maka akan meningkatkan laba bersih pada PT Bank BRI Syariah.

Hasil penelitian ini sejalan dengan penelitian yang telah dilakukan oleh Suaidah (2020) tentang pengaruh pembiayaan musyarakah terhadap laba bersih bank umum syariah. 


\section{SIMPULAN}

Berdasarkan hasil penelitian ini mengungkapkan bahwa secara simultan pembiayaan mudharabah $\left(\mathrm{X}_{1}\right)$ dan pembiayaan musyarakah $\left(\mathrm{X}_{2}\right)$ mempengaruhi laba bersih secara positif signifikan. Pada pembiayaan mudharabah $\left(\mathrm{X}_{1}\right)$ terhadap laba bersih tidak terdapat pengaruh, jika terjadi kenaikan ataupun penurunan pada pembiayaan mudharabah tidak akan berpengaruh pada laba bersih. Pada pembiayaan musyarakah $\left(\mathrm{X}_{2}\right)$ terhadap laba bersih berpengaruh positif signifikan, jika semakin besar pendapatan yang diperoleh melalui pembiayaan musyarakah maka akan meningkatkan laba bersih.

Diharapkan peneliti selanjutnya dapat menambahkan pada varibelnya karena terdapat berbagai macam produk perbankan syariah di Indonesia seperti pembiayaan murabahah, ijarah, atau pembiayaanpembiayaan syariah lainnya yang dapat meningkatkan jumlah laba bersih yang diperoleh pada bank syariah di Indonesia.

\section{DAFTAR PUSTAKA}

Alma, B., \& Donni, J. P. (2014). Manajemen Bisnis Syariah. Alfabeta.

Ascarya. (2011). Akad \& Produk Bank Syariah. PT. Raja Grafindo Persada.

Ghozali, I. (2017). Aplikasi Analisis Multivariate Dengan Program IBM SPSS 21. Badan Penerbit Universitas Diponegoro.

Harahap, S. S. (2008). Teori Akuntansi. PT Raja Grafindo Persada.

Islahuzzaman. (2012). Istilah-istilah Akuntansi dan Auditing. Bumi Aksara.

Ismail. (2011). Perbankan Syari'ah. Kencana.

Kasmir. (2014). Analisis Laporan Keuangan. PT Raja Grafindo Persada.

Monika, S. (2019). Pengaruh Pembiayaan Mudharabah Dan Pembiayaan Murabahah Terhadap Laba Bersih Pada Bank Syariah Mandiri Periode 20162018. Science of Management and Students Research Journal, 1(3), 113-122.

Nurawwalunnisa. (2017). Pengaruh Pembiayaan Mudharabah, Pembiayaan Murabahah Dan Ijarah Terhadap Laba Perbankan Syariah Indonesia (Bank Syariah Mandiri). EKONOBIS, 3(1), 21-28.

Suaidah, I. (2020). Pengaruh Pembiayaan Mudharabah Dan Pembiayaan Musyarakah Terhadap Laba Bersih Pada PT. Bank Syariah Bukopin Periode 2015-2019. Manajemen dan Inovasi(MANOVA), 3 , $17-27$. http://repository.uinsu.ac.id/id/eprint/9252

Sudarsono, H. (2004). Bank dan Lembaga Keuangan Syariah. P3EI.

www.idx.co.id

ir-bankbsi.com 